\title{
Canned sea fish marketed in Serbia: their zinc, copper, and iron levels and contribution to the dietary intake
}

\author{
Aleksandar R. Popović1, Dubravka J. Relić1 , Danijela V. Vranić , Jelena A. Babić-Milijašević², \\ Lato L. Pezo ${ }^{3}$, and Jasna M. Đinović-Stojanović \\ Faculty of Chemistry, University of Belgrade ${ }^{1}$, Institute of Meat Hygiene and Technology ${ }^{2}$, Institute of General and \\ Physical Chemistry, University of Belgrade ${ }^{3}$, Belgrade, Serbia
}

[Received in November 2017; Similarity Check in November 2017; Accepted in February 2018]

\begin{abstract}
The aim of this study was to determine the levels of $\mathrm{Zn}, \mathrm{Cu}$, and $\mathrm{Fe}$ in three canned fish species marketed Serbia to see if they meet recommended daily intake requirements or exceed safety limits. We collected a total of 207 samples of canned tuna, sardine, and mackerel, in oil or tomato sauce and analysed them with inductively coupled plasma mass spectrometry (ICP-MS) after acid digestion. The highest levels were obtained for $\mathrm{Zn}\left(15.1 \mathrm{mg} \mathrm{kg}^{-1}\right)$ and $\mathrm{Cu}\left(1.37 \mathrm{mg} \mathrm{kg}^{-1}\right)$ in sardine in oil and tomato sauce, respectively, and for $\mathrm{Fe}\left(18.98 \mathrm{mg} \mathrm{kg}^{-1}\right)$ in mackerel in tomato sauce. Our results keep within the ranges reported by several national food databases and available literature data, with a few exceptions. Our findings also single out canned sardines as the richest source of the three essential elements combined. The estimated daily intake (EDI) of the three essential elements, however, was subpar, and ranged between $0.14 \%$ and $0.72 \%$ of the recommended dietary allowance (RDA) for $\mathrm{Zn}, \mathrm{Cu}$, and $\mathrm{Fe}$.
\end{abstract}

KEY WORDS: EDI, essential elements; fish products; ICP-MS; local markets; RDA

Fish and seafood are important sources of high-quality proteins, essential fatty acids, vitamins, and minerals. Fish proteins are considered easily digestible and rich in essential amino acids (1). Eating a low-fat source of protein such as seafood can confer health benefits on the cardiovascular system and on brain and eye development (2). Omega-3polyunsaturated fatty acids (PUFA) also provide a broad range of health benefits which are not found in any other fats (3-5). In addition, fish is considered an excellent source of vitamins A, D, B3, B6, and B12, which are necessary for growth, bone development, hydrogen transfer reactions, and normal functioning of the brain and the nervous system (6).

Seafood is almost the only natural source of iodine. Essential trace elements such as zinc, copper, and iron (7) are found in significant amounts, particularly in fish species eaten with bones, such as small indigenous fish species $(8$, 9). However, at high levels all metals can be toxic. Consequently, both the scientific community and consumers have shown a growing interest in the health benefits and potential risks of fish and fish product consumption $(1,10$ 12).

According to Statistical Office of the Republic of Serbia (13), fish consumption is on the rise, especially over religious holidays at the end of the year, and so is the scientific interest for fish and fish products $(11,12,14-17)$. Research so far, however, has focused on the river fish, especially from the

Correspondence to: Aleksandar Popović, Faculty of Chemistry, University of Belgrade, Studentski trg 12-16, 11000 Belgrade, Serbia

E-mail:apopovic@chem.bg.ac.rs
Danube as the Serbian largest river. Investigations of canned fish from the local Serbian markets mostly refer to an analysis of inorganic and organic environmental contaminants $(16,17)$ and proximate composition (18). To the best of our knowledge, however, no one has investigated the levels of essential elements in canned tuna, sardine (or pilchard), and mackerel available in Serbian markets and compared them to the numerous studies worldwide (19-23). Information on the levels of essential element as well as the estimated daily intake (EDI) of these elements by adults consuming different species of canned fish is important to ensure that the fish consumed is safe for human consumption. Furthermore information about zinc, copper, and iron levels in canned fish are required by Serbian regulations (24).

The objectives of this study were therefore to: 1) acquire information about the levels of zinc, copper, and iron in the three marketed canned fish species available in Serbia; 2) compare these levels between canned fish species in oil and tomato sauce; 3 ) assess the patterns of their distribution among these canned fish; 4) ascertain whether they exceed maximum levels currently in force (24); and 5) calculate their intake by consumers through canned fish.

\section{MATERIALS AND METHODS}

\section{Sample collection and preparation}

Canned tuna $(n=72)$, sardine $(n=45)$, and mackerel $(n=21)$ in oil and tomato sauce $(n=33, n=18$, and $n=18$, respectively) were purchased at Serbian retail markets in 
2015. The cans were labelled, taken to the laboratory, and stored in a clean dry place until preparation. Samples were then homogenised, $0.5 \mathrm{~g}$ placed in a Teflon vessel, mineralised by adding $5 \mathrm{~mL}$ of nitric acid $(69.5 \%$, Fluka, Buchs, Switzerland) and $1.5 \mathrm{~mL}$ of hydrogen peroxide (30\% analytical grade, Merck, Darmstadt, Germany), and digested in a Multiwave 3000 SOLVE microwave digester (Anton Paar, Graz, Austria). The digestion conditions were as follows: max power $1000 \mathrm{~W}$; ramped to $180{ }^{\circ} \mathrm{C}$ over $5 \mathrm{~min}$; held at $180{ }^{\circ} \mathrm{C}$ for $15 \mathrm{~min}$; cooled in the oven for $20 \mathrm{~min}$ and then at room temperature for another $15 \mathrm{~min}$. Cooled to room temperature, the digests were moved to polypropylene volumetric flasks and diluted to $100 \mathrm{~mL}$ with deionised, Milli-Q water (Milli-RO 60, Millipore Corporation, Billerica, MA, USA). $\mathrm{Zn}, \mathrm{Cu}$, and Fe were analysed with an iCap Q inductively coupled plasma mass spectrometer (ICP-MS) (Thermo Scientific, Bremen, Germany). For quantification we used the most abundant isotopes. For five-point calibration (including zero) we used standard stock solutions containing $1000 \mathrm{mg} \mathrm{L}^{-1}$ of each element ( $\mathrm{Zn}, \mathrm{Cu}$, and $\mathrm{Fe}$ ) obtained from Solutions Plus, Inc. (Fenton, MO, USA). The purity of the starting material in the standards was $99.999 \%$ for each element. Linear ranges and coefficients of determination (R) were $>0.99$ for all elements. Before calibration, the instrument was auto-tuned for the highest sensitivity.

\section{Quality assurance}

Accuracy was tested with BCR-185R bovine liver (IRMM, Geel, Belgium) as certified reference material. It was prepared in the same manner as the canned fish samples. Measured concentrations were corrected for response factors of internal standards using interpolation and were within the range of the certified values for all isotopes (Table 1). As no information was given regarding Fe content in the reference material, analytical recoveries of $95-101 \%$ were determined using spiked samples $\left(\mathrm{Fe}=10 \mathrm{mg} \mathrm{kg}^{-1}\right.$; $\mathrm{n}=10)$.

\section{Estimated daily intake}

To calculate the estimated daily intake (EDI) of $\mathrm{Zn}, \mathrm{Cu}$, and $\mathrm{Fe}$ through consumption of the analysed canned fish we used the following equation:

$$
\text { EDI }\left(\mathrm{mg} \mathrm{day}^{-1}\right)=\mathrm{C}_{\text {elements }} \times \mathrm{DC}_{\text {canned fish }}
$$

where $\mathrm{C}_{\text {elements }}$ is the level of the element $\left(\mathrm{mg} \mathrm{kg}^{-1}\right)$ measured in canned fish and $\mathrm{DC}_{\text {canned fish }}$ is the average daily consumption of canned fish per person. In Serbia it is $3.04 \mathrm{~g}$, according to the Statistical Office of the Republic of Serbia (13).

\section{Statistical analysis}

Statistical analysis was run on Statistica 10.0 (StatSoft Inc., Tulsa, OK, USA). To establish significant differences between the means, we used the analysis of variance (ANOVA) and Tukey's HSD test.

\section{RESULTS AND DISCUSSION}

Table 2 shows the mean levels of $\mathrm{Zn}, \mathrm{Cu}$, and $\mathrm{Fe}$ in 207 canned tuna, sardine, and mackerel samples in oil and tomato sauce, as well as their ranges taken from several national food databases (NFDs) (25-36). Significant differences between the three types of canned fish in oil and tomato sauce are presented in Figure 1.

The highest levels of $\mathrm{Fe}$ were found in canned sardine in oil and mackerel in tomato sauce Canned sardine in oil and tomato sauce also had the highest levels of $\mathrm{Zn}$ and $\mathrm{Cu}$ (Table 2).

\section{Zinc}

Zn has an important role in many biochemical reactions in human metabolism and is often called the metal of life (37-39). In our study, canned sardine had significantly higher $\mathrm{Zn}$ levels than the rest (Figure 1A), but these still keep within the ranges reported in by other nations (NFDs in Table 2), as do the levels in the other two fish.

\section{Copper}

$\mathrm{Cu}$ is an important essential element that acts as a cofactor for many redox enzymes. However, at high levels it can become toxic and lead to anaemia by interfering with iron transport and/or metabolism (40). However, Bost et al. (41) point to a number of issues that blur the relationship between $\mathrm{Cu}$ intake and health. In our study, canned sardine again had the highest $\mathrm{Cu}$ levels, but not significantly higher than mackerel (Figure 1B). Cu levels in canned fish in oil were well within the NFD ranges, but were lower than the NFD data in canned sardine in tomato sauce (Table 2).

Table 1 Limit of detection (LOD) and assigned and measured concentrations of the BCR-185R reference material used for quality control $(n=10)$

\begin{tabular}{lcccc}
\hline \multirow{2}{*}{ Elements } & LOD & Certified value $^{\mathbf{a}}$ & Analysed value & Recovery \\
\cline { 2 - 5 } & $\mathbf{( \mathbf { m g ~ k g } ^ { - 1 } )}$ & $\left.\mathbf{( m g ~ k g}^{-1}\right)$ & $\left(\mathbf{m g ~ k g}^{-1}\right)$ & $\mathbf{( \% )}$ \\
\hline $\mathrm{Zn}$ & 0.158 & $138.6 \pm 2.1$ & $135.9 \pm 1.8$ & 98.1 \\
\hline $\mathrm{Cu}$ & 0.042 & $277 \pm 5$ & $271 \pm 6$ & 97.8 \\
\hline $\mathrm{Fe}$ & 0.11 & - & - & - \\
\hline
\end{tabular}

The data are presented as means \pm standard deviation

${ }^{a}$ Certified value as given by the manufacturer 
Table 2 Levels (Mean $\pm S D, m g \mathrm{~kg}^{-1}$ ) of essential elements in canned fish in oil and tomato sauce purchased in Serbian markets and ranges of these elements published in national food databases

\begin{tabular}{|c|c|c|c|c|c|c|c|}
\hline \multirow{3}{*}{ Elements } & \multirow{3}{*}{ MRL $^{a}$} & \multicolumn{6}{|c|}{ Canned fish in oil } \\
\hline & & \multicolumn{2}{|c|}{ Tuna $(n=72)$} & \multicolumn{2}{|c|}{ Sardine $(n=45)$} & \multicolumn{2}{|c|}{ Mackerel $(n=21)$} \\
\hline & & Our data & NFDs $^{b}$ & Our data & NFDs & Our data & NFDs \\
\hline $\mathrm{Zn}$ & 100.0 & $7.71 \pm 3.97$ & $6-20$ & $15.1 \pm 9.09$ & $13.1-23$ & $7.59 \pm 3.38$ & $5.0-27.0$ \\
\hline $\mathrm{Cu}$ & 30.0 & $0.86 \pm 0.95$ & $0.51-2$ & $1.28 \pm 1.04$ & $1.1-1.86$ & $0.84 \pm 0.57$ & $0.4-2.8$ \\
\hline $\mathrm{Fe}$ & 30.0 & $8.19 \pm 4.35$ & $8.4-48$ & $13.8 \pm 7.00$ & $20-31$ & $9.90 \pm 4.99$ & $9-20.4$ \\
\hline \multirow{3}{*}{ Elements } & \multirow{3}{*}{ MRL } & \multicolumn{6}{|c|}{ Canned fish in tomato sauce } \\
\hline & & \multicolumn{2}{|c|}{ Tuna $(n=33)$} & \multicolumn{2}{|c|}{ Sardine $(n=18)$} & \multicolumn{2}{|c|}{ Mackerel $(n=18)$} \\
\hline & & Our data & NFDs & Our data & NFDs & Our data & NFDs \\
\hline $\mathrm{Zn}$ & 100.0 & $8.93 \pm 4.94$ & 18 & $14.05 \pm 3.38$ & $14-31$ & $9.48 \pm 3.26$ & $5-9.3$ \\
\hline $\mathrm{Cu}$ & 30.0 & $0.91 \pm 0.71$ & 0.53 & $1.37 \pm 0.53$ & $2.4-2.72$ & $1.05 \pm 0.51$ & $<1-1.1$ \\
\hline $\mathrm{Fe}$ & 30.0 & $9.76 \pm 5.13$ & 12.0 & $16.78 \pm 8.24$ & $15-37$ & $18.98 \pm 3.30$ & $6.95-13$ \\
\hline
\end{tabular}

${ }^{a}$ MRL-maximum residue level (mg $\left.\mathrm{kg}^{-1}\right)$ for element in fish and other seafood products according to Serbian regulation (24); ${ }^{b}$ National Food Databases, NFDs $\left(\mathrm{mg} \mathrm{kg}^{-1}\right)$, (25-36)
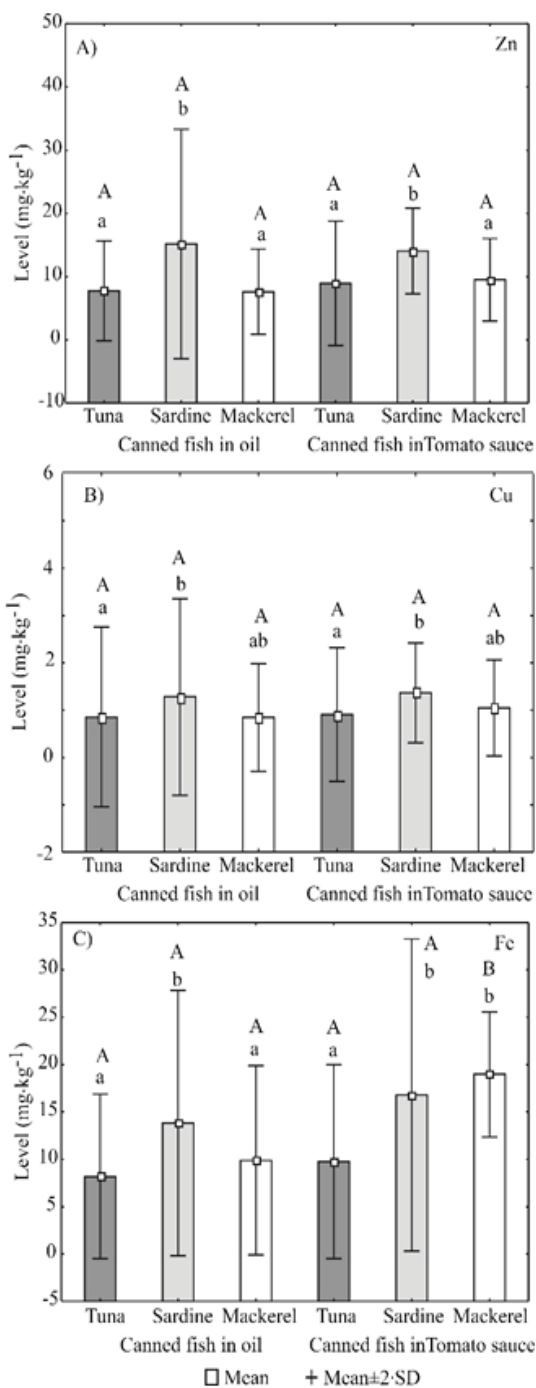

Figure $1 \mathrm{Zn}, \mathrm{Cu}$, and Fe levels in canned tuna, sardine, and mackerel in oil and tomato sauce. Data are presented as means $\pm S D$. Different lowercase letters in the bars indicate significant differences between canned fish in the same sauce, while different uppercase letters indicate significant differences between the same canned fish in different sauces (Tukey's HSD test; $p<0.05$ )
Iron

Similar to Zn, Fe is an important element available in abundance in poultry, fish, meat, cereals, grains, fruits, and other vegetables (42). It constitutes haemoglobin in blood, myoglobin in the muscles, and participates in a wide variety of metabolic processes. Disorders of Fe metabolism are among the most common diseases in humans, including anaemia, iron overload, and neurodegenerative diseases.

Third time winner, canned sardine showed significantly higher Fe levels than the other two canned fish in oil (Figure 1C). Fe levels kept within the range reported by the NFDs for all three fish, except for sardine in oil and mackerel in tomato sauce, which had lower and higher values, respectively (Table 2). In addition, Tukey's HSD test showed a significant difference in Fe levels between mackerel canned in oil and in tomato sauce $(\mathrm{p}<0.05$ level) (Figure 1C). In fact, they were the highest not only in this study but in the available literature reporting Fe levels in canned mackerel in tomato sauce $(19,23)$, which, to be honest, is relatively modest.

\section{Intake of essential elements by consumers through} canned fish

Table 3 shows the estimated daily intake of the analysed essential elements, based on the average Serbian consumption of canned fish per person. These estimates are for adults aged 19-50 years. The results are expressed as the percentage of the recommended dietary allowance (RDA) published by the Institute of Medicine, Washington, USA (43).

Overall, canned fish was estimated to provide between 0.14 and $0.72 \%$ of the RDA and are, therefore, not important dietary sources of these three essential elements. Other food types are clearly necessary to make up for difference in Serbian population. In terms of maximum allowed limits, however, these three essential elements in 
Table 3 Estimated daily intake (EDI) of essential elements based on the average Serbian per capita consumption of canned fish (3.04 $\mathrm{g}$ person $^{-1}$ day $^{-1}$ )

EDI (\% of the RDA)

Canned fish in oil (o) and tomato sauce (t)

\begin{tabular}{|c|c|c|c|c|c|c|c|c|c|c|c|c|c|c|}
\hline \multirow{2}{*}{ Elements } & \multicolumn{2}{|c|}{$\begin{array}{c}\text { RDA }^{\mathrm{a}} \\
\left(\mathrm{mg} \mathrm{day}^{-1}\right)\end{array}$} & \multicolumn{4}{|c|}{ Tuna } & \multicolumn{4}{|c|}{ Sardine } & \multicolumn{4}{|c|}{ Mackerel } \\
\hline & M & $\mathbf{F}$ & Mo & Mt & Fo & Ft & Mo & Mt & Fo & Ft & Mo & Mt & Fo & Ft \\
\hline $\mathrm{Zn}$ & 11 & 8 & 0.21 & 0.25 & 0.29 & 0.34 & 0.42 & 0.39 & 0.57 & 0.53 & 0.21 & 0.26 & 0.29 & 0.36 \\
\hline $\mathrm{Cu}$ & 0.9 & 0.9 & 0.29 & 0.31 & 0.29 & 0.31 & 0.43 & 0.46 & 0.43 & 0.46 & 0.28 & 0.35 & 0.28 & 0.35 \\
\hline $\mathrm{Fe}$ & 8 & 18 & 0.31 & 0.37 & 0.14 & 0.16 & 0.52 & 0.64 & 0.23 & 0.28 & 0.38 & 0.72 & 0.17 & 0.32 \\
\hline
\end{tabular}

${ }^{a} R D A$ - recommended dietary allowance (RDA) for men $(M)$ and women $(F)$ between 19 and 50 years of age (43)

canned fish meet the Serbian marketing requirements (24)

(Table 2).

\section{CONCLUSION}

Our findings are pretty much within the ranges reported by other nations (NFDs), which is no surprise, especially as the canned fish marketed in Serbia is imported from a number of countries whose NFDs have been referenced here. The levels of the three elements do not present any health risk, but also barely contribute to the daily intake requirements. However, our findings also single out sardines as the most complete nutritional meal of the three, at least in terms of $\mathrm{Cu}, \mathrm{Fe}$, and $\mathrm{Zn}$. Canned sardine contributed to the RDI about 1.5 times as much as canned tuna or mackerel. However, canned fish cannot be considered an important dietary source of the analyzed essential elements, and other food types or dramatic changes in fish diet are clearly necessary to make up for the difference in Serbian populations.

Our study may be limited in design, considering that it focused only on the canned sea fish and did not compare canned with fresh fish or that the EDI calculation is based on crude estimates, yet the merits of monitoring elements in foodstuffs are indisputable: monitoring ensures the quality and safety of food marketed locally and can provide useful information about essential nutrients to the (local) consumer.

\section{Conflicts of interest}

None to declare. The authors alone are responsible for the content of this article.

\section{Acknowledgements}

This work was supported by the Ministry of Education, Science and Technological Development of the Republic of Serbia (grant numbers OI 172001, TR 31075, and TR 31055).

\section{REFERENCES}

1. Costa LG. Contaminants in fish: risk-benefit consideration. Arh Hig Rada Toksikol 2007;58:367-74. doi: 10.2478/ v10004-007-0025-3

2. Nesheim MC, Yaktine AL, editors. Seafood Choices: Balancing Benefits and Risks. Washington (DC): The National Academies Press; 2007.

3. Hooper L, Thompson RL, Harrison RA, Summerbell CD, Ness AR, Moore HJ, Worthington HV, Durrington PN, Higgins JP, Capps NE, Riemersma RA, Ebrahim SB, Davey Smith G. Risks and benefits of omega 3 fats for mortality, cardiovascular disease, and cancer: systematic review. BMJ 2006;332:752-60. doi: 10.1136/bmj.38755.366331.2F

4. Domingo JL, Bocio A, Falcó G, Llobet JM. Benefits and risks of fish consumption: part I. A quantitative analysis of the intake of omega-3 fatty acids and chemical contaminants. Toxicology 2007;230:219-26. doi: 10.1016/j.tox.2006.11.054

5. Filion KB, El Khoury F, Bielinski M, Schiller I, Dendukuri N, Brophy JM. Omega-3 fatty acids in high-risk cardiovascular patients: a meta-analysis of randomized controlled trials. BMC Cardiovasc Disord 2010;10:24. doi: 10.1186/14712261-10-24

6. Food and Agriculture Organization of the United Nations / World Health Orgaization (FAO/WHO). Human Vitamin and Mineral Requirements. Report of a joint FAO/WHO expert consultation Bangkok, Thailand. Rome: Food and Nutrition Division FAO; 2001.

7. Fraga CG. Relevance, essentiality and toxicity of trace elements in human health. Mol Aspects Med 2005;26:235-44. doi: 10.1016/j.mam.2005.07.013

8. Roos N, Wahab MA, Chamnan C, Thilsted SH. The role of fish in foodbased strategies to combat vitamin A and mineral deficiencies in developing countries. J Nutr 2007;137:11069. PMID: 17374688

9. Zhao L, Xia Z, Wang F. Zebrafish in the sea of mineral (iron, zinc, and copper) metabolism. Front Pharmacol 2014;5:33. doi: 10.3389/fphar.2014.00033

10. Squadrone S, Burioli E, Monaco G, Koya MK, Prearo M, Gennero S, Dominici A, Abete MC. Human exposure to metals due to consumption of fish from an artificial lake basin close to an active mining area in Katanga (D.R. Congo). Sci Total Environ 2016;568:679-84. doi: 10.1016/j. scitotenv.2016.02.167

11. Subotić S, Spasić S, Višnjić-Jeftić Ž, Hegediš A, KrpoĆetković J, Mićković B, Skorić S, Lenhardt M. Heavy metal and trace element bioaccumulation in target tissues of four edible fish species from the Danube River (Serbia). 
Ecotoxicol Environ Saf 2013;98:196-202. doi: 10.1016/j. ecoenv.2013.08.020

12. Subotić S, Višnjić Jeftić Ž, Spasić S, Hegediš A, KrpoĆetković J, Lenhardt M. Distribution and accumulation of elements ( $\mathrm{As}, \mathrm{Cu}, \mathrm{Fe}, \mathrm{Hg}, \mathrm{Mn}$, and $\mathrm{Zn}$ ) in tissues of fish species from different trophic levels in the Danube River at the confluence with the Sava River (Serbia). Environ Sci Pollut Res 2013;20:5309-17. doi: 10.1007/s11356-013-15223

13. Statistical Office of the Republic of Serbia. Household Budget Survey, 2013 (displayed 08 September 2017). Available at http://www.stat.gov.rs/WebSite/repository/ documents/00/01/56/88/SB_583-APD-2013.pdf

14. Visnjic-Jeftic Z, Jaric I, Jovanovic Lj, Skoric S, SmederevacLalic M, Nikcevic M, Lenhardt M. Heavy metal and trace element accumulation in muscle, liver and gills of the Pontic shad (Alosa immaculata Bennet 1835) from the Danube River (Serbia). Microchem J 2010;95:341-4. doi: 10.1016/j. microc.2010.02.004

15. Sunjog K, Gačić Z, Kolarević S, Višnjić-Jeftić Ž, Jarić I, Knežević-Vukčević J, Vuković-Gačić B, Lenhardt M. Heavy metal accumulation and the genotoxicity in Barbel (Barbus barbus) as indicators of the Danube River pollution. Sci World J 2012;2012:351074. doi: 10.1100/2012/351074

16. Škrbić B, Živančev J, Mrmoš N. Concentrations of arsenic, cadmium and lead in selected foodstuffs from Serbian market basket: estimated intake by the population from the Serbia. Food Chem Toxicol 2013;58:440-8. doi: 10.1016/j. fct.2013.05.026

17. Novakov NJ, Mihaljev ŽA, Kartalović BD, Blagojević BJ, Petrović JM, Ćirković MA, Rogan DR. Heavy metals and PAHs in canned fish supplies on the Serbian market. Food Addit Contam B 2017;10:208-15. doi: 10.1080/19393210.2017.1322150

18. Marković G, Mladenović J, Cvijović M, Miljković J. Total protein and lipid contents of canned fish on the Serbian market. Acta Agric Serb 2015;20:67-74.

19. Ikem A, Egiebor NO. Assessment of trace elements in canned fishes (mackerel, tuna, salmon, sardines and herrings) marketed in Georgia and Alabama (United States of America). J Food Comp Anal 2005;18:771-87. doi: 10.1016/j. jfca.2004.11.002

20. Ashraf W, Seddigi Z, Abulkibash A, Khalid M. Levels of selected metals in canned fish consumed in Kingdom of Saudi Arabia. Environ Monit Assess 2006;117:271-9. doi: 10.1007/ s10661-006-0989-5

21. Tuzen M, Soylak M. Determination of trace metals in canned fish marketed in Turkey. Food Chem 2007;101:1378-82. doi: 10.1016/j.foodchem.2006.03.044

22. Hosseini SV, Sobhanardakani S, Miandare HK, Harsij M, Regenstein JM. Determination of toxic $(\mathrm{Pb}, \mathrm{Cd})$ and essential $(\mathrm{Zn}, \mathrm{Mn})$ metals in canned tuna fish produced in Iran. J Environ Health Sci Eng 2015;13:59. doi: 10.1186/s40201015-0215-x

23. Iwegbue CMA. Metal concentrations in selected brands of canned fish in Nigeria: estimation of dietary intakes and target hazard quotients. Environ Monit Assess 2015;187:85. doi: 10.1007/s10661-014-4135-5

24. Serbian Regulation. Pravilnik o maksimalno dozvoljenim količinama ostataka sredstava za zaštitu bilja u hrani i hrani za životinje i o hrani za životinje za koju se utvrđuju maksimalno dozvoljene količine ostataka sredstava za zaštitu bilja [Maximum allowed contents of contaminants in food and feed, in Serbian]. Službeni glasnik RS no. 29/2014, 37/2014 \& 39/2014).

25. BDA. Food Composition Database for Epidemiological Studies in Italy (Banca Dati di Composizione degli Alimenti per Studi Epidemiologici in Italia - BDA [displayed 19 February 2017]. Available at http://www.bda-ieo.it/ wordpress/en/

26. National Food Composition Database in Finland. The National Institute for Health and Welfare [displayed 19 February 2017]. Available at www.fineli.fi

27. Government of Canada. Canadian Nutrient File (CNF) [displayed 19 February 2017]. Available at https://foodnutrition.canada.ca/cnf-fce/index-eng.jsp

28. DTU food. National Food Institute - Danish Food Composition Databank [displayed 19 February 2017]. Available at http:// www.foodcomp.dk/v7/fcdb_default.asp

29. Livsmedelsverket. National Food Agency, Sweden [displayed 19 February 2017]. Available at https://www.livsmedelsverket. se/en

30. Matis. ISGEM (The Icelandic Food Composition Database) [displayed 19 February 2017]. Available at http://old.matis. is/english/service/product-development-andentrepreneurship/nutrition/isgem-the-icelandic-foodcomposition-database/

31. Norwegian Food Safety Authority. Norwegian Food Composition Database 2016. The Norwegian Directorate of Health and University of Oslo [displayed 19 February 2017]. Available at http://www.matvaretabellen.no.

32. The Swiss Food Composition Database. Federal Food Safety and Veterinary Office (FSVO) [displayed 19 February 2017]. Available at http://www.naehrwertdaten.ch/ request? $\mathrm{xml}=$ MessageData\&xml=MetaData\&xs1= Start\&lan=de\&pageKey=Start

33. United States Department of Agriculture, Agricultural Research Service. USDA Food Composition database [displayed 19 February 2017]. Available at https://ndb.nal. usda.gov/ndb/

34. Czech Food Composition Database [displayed 19 February 2017]. Available at http://www.nutridatabaze.cz/en/

35. French Agency for Food, Environmental and Occupational Health \& Safety. The ANSES-CIQUAL food composition table [displayed 19 February 2017]. Available at https://www. anses.fr/en/content/anses-ciqual-food-composition-table

36. The Dutch Food Composition Database (NEVO). National Institute for Public Health and the Environment. [displayed 19 February 2017]. Available at https://www.rivm.nl/en/ Topics/D/Dutch_Food_Composition_Database

37. Maret W. Zinc biochemistry: from a single zinc enzyme to a key element of life. Adv Nutr 2013;4:82-91. doi: 10.3945/ an.112.003038

38. Prasad AD. Discovery of human zinc deficiency: it's impact on human health and disease. Adv Nutr 2013;4:176-90. doi: 10.3945/an.112.003210

39. Roohani N, Hurrell R, Kelishadi R, Schulin R. Zinc and its importance for human health: An integrative review. J Res Med Sci 2003;18:144-57. PMCID: PMC3724376

40. Ralph A, McArdle HJ. Copper metabolism and requirements in the pregnant mother, her fetus, and children: A Critical Review. New York (NY): International Copper Association; 2001. 
41. Bost M, Houdart S, Oberli M, Kalonji E, Huneau J-F, Margaritis I. Dietary copper and human health: Current evidence and unresolved issues. J Trace Elem Med Biol 2016;35:107-15. doi: 10.1016/j.jtemb.2016.02.006

42. Whitney E, Rolfes SR. Understanding Nutrition. $14^{\text {th }}$ ed. Stamford (CT): Cengage Learning; 2015.
43. Institute of Medicine (US) Panel on Micronutrients. Food and Nutrition Board. Dietary Reference Intakes for Vitamin A, Vitamin K, Arsenic, Boron, Chromium, Copper, Iodine, Iron, Manganese, Molybdenum, Nickel, Silicon, Vanadium, and Zinc. Washington (DC): National Academy Press; 2001.

\section{Konzervirana morska riba na srpskome tržištu: razine cinka, bakra i željeza i njihov doprinos dnevnom unosu ovih esencijalnih metala}

Cilj ovoga rada bio je utvrditi razinu cinka, bakra i željeza u trima vrstama ribljih konzervi sa srpskoga tržišta kako bi se ustanovilo zadovoljavaju li zahtjeve za preporučenim dnevnim unosom, ili pak prekoračuju sigurnosne granice. Sadržaj esencijalnih elemenata utvrđen je u ukupno 207 uzoraka konzerve tune, sardine i skuše primjenom masene spektrometrije s induktivno spregnutom plazmom (ICP-MS) nakon kisele digestije uzoraka. Najveći sadržaj cinka $\left(15,1 \mathrm{mg} \mathrm{kg}^{-1}\right) \mathrm{utvrđen}$ je u sardini u ulju, bakra $\left(1,37 \mathrm{mg} \mathrm{kg}^{-1}\right)$ u sardini u umaku od rajčice, a željeza $\left(18,98 \mathrm{mg} \mathrm{kg}^{-1}\right)$ u skuši u umaku od rajčice. Dobiveni rezultati su u opsegu vrijednosti za analizirane elemente koje je objavilo nekoliko nacionalnih baza podataka o hrani, kao i u opsegu dostupnih literaturnih podataka, s nekoliko iznimaka. Rezultati istraživanja izdvajaju sardinu u konzervi kao najbogatiji izvor proučavanih esencijalnih elementa. Procijenjeni dnevni unos (EDI) bio je između 0,14 \% i $0,72 \%$ preporučenih dnevnih unosa cinka, bakra i željeza. Iako sardina u konzervi, u odnosu na tunu i skušu, doprinosi oko 1,5 puta više preporučenom dnevnom unosu (RDI) esencijalnih elemenata, konzervirana morska riba ne može se smatrati značajnim izvorom cinka, bakra i željeza u prehrani srpskoga stanovništva.

KLJUČNE RIJEČI: esencijalni elementi; ICP-MS; lokalno tržište; preporučeni dnevni unos (RDA); procjena dnevnog unosa (EDI); riblji proizvodi 